\title{
Building bridges and constructing walls: Subject hierarchies as reflected in teachers' perspectives towards student influence
}

\author{
Valgerður S. Bjarnadóttir
}

- Abstract $\quad$ Um höfundinn $\quad$ About the author $\quad$ Heimildir

The aim of this study is to explore how teachers from various academic subjects and programmes describe their pedagogic practice, particularly regarding students' opportunities to influence what and how they learn, and whether and how their descriptions reflect subject hierarchies. The study draws on interviews with 16 upper secondary school teachers in Iceland, representing different schools and subjects.

Bernstein's theory of pedagogic discourse was used to prepare this study. The study shows how teacher perceptions of pedagogic practice in relation to student influence in the school context reflect the constructions of subject hierarchies. Teachers in mathematics reported on rigid pedagogic practices while teachers in other subjects described pedagogic practices in which students could, to some extent, influence their learning. Furthermore, teachers in social science subjects, natural science subjects, and languages described attempts to build bridges between various subjects, while mathematics did not participate in such attempts.

Those constructions indicate an upper secondary school in which mathematics, particularly within the natural science programme, is strongly classified, as defined by Bernstein. The findings mirror stereotypical notions of students' capacity and interest since students enrolled in programmes other than the natural science programme are perceived by the teachers as lacking the ability to succeed in mathematics. The teachers described how conceptual demands in mathematics were lowered in other academic programmes, leading to knowledge roadblocks for students and restricting their further educational opportunities.

Key words: Upper secondary education, student influence, subject hierarchies, pedagogic discourse, knowledge roadblocks

\section{Introduction}

Legislation and national curricula in the Nordic countries reflect the view that students should be provided with considerable influence in everyday classroom practice (Arnesen, Lahelma, Lundahl, \& Öhrn, 2014). This view has indeed been part of Icelandic education policy for decades (Harðarson, 2010; Reynisdóttir \& Jóhannesson, 2013) but framed more explicitly in current legislation and curriculum (Ministry of Education, Science and Culture, 2012; Upper Secondary School Act No. 92/2008). The current curriculum presents six fundamental pillars of education that serve as overarching aims of education. These include, among others, democracy and human rights, sustainability, and equality (Ministry of Education, Science and Culture, 
2012). The pillars represent a vision of a society in which young people have a role and willingness to exercise influence. Furthermore, the current Icelandic Upper Secondary School Act (No. $92 / 2008$, Article 33) stipulates that students have the right to state their opinions on school environment and practices and that their opinions should be addressed and considered.

Recent studies in the field have shown that students' opportunities to influence their learning vary between subjects or programmes (see e.g. Bjarnadóttir \& Geirsdóttir, 2018; Hjelmér \& Rosvall, 2016). According to Lundahl (2014), one reason for the difficulties students experience in influencing their education is that student influence might be perceived as an obstacle to performance of both schools and students. International studies show that subjects near the top of the hierarchy, such as mathematics and the natural science subjects (Bleazby, 2015; Jonsson \& Beach, 2017; Lynch \& McGarr, 2016; Muller, 2006; Ward, 2012), are usually less open to innovation and influence (Bernstein, 2000; Cause, 2010; Hjelmér, 2011).

The inverse relationship between student influence and subject hierarchy sparked an interest in pursuing further study. The aim of the study is to explore how upper secondary school teachers from various subjects describe their pedagogic practice in relation to student influence. More specifically, this article analyses whether and how traditional subject hierarchies are reflected in the teachers' descriptions of student influence. Research in the field has focused on the differences between academic and vocational tracks (Eiríksdóttir, Ragnarsdóttir, og Jónasson, 2018; Niemi \& Rosvall, 2013; Nylund et al., 2018; Nylund, Rosvall, \& Ledman, 2017; Sych, 2016), while this study reports on possible differences between academic programmes, as reflected by teachers' views and reported practices.

\section{Background}

While the current educational policy for upper secondary education in Iceland emphasises student influence at greater depth than previously, the policy does not stipulate what students should be able to influence and how. This paper looks to Basil Bernstein's (2000) theory of pedagogic discourse for the conceptualisation and understanding of student influence in relation to pedagogic practice which provides a useful account of exploring and analysing everyday pedagogic practice and curricula in the context of knowledge hierarchies and positions of power. A central argument in Bernstein's (2000) theory is that the school produces a hierarchy in which pedagogic practice is an essential social context that determines the success and failure of students.

Two of Bernstein's (2000) fundamental concepts, classification and framing, are used to analyse the way in which the education system privileges certain forms of knowledge and styles of pedagogy over others. Classification explains the boundaries between categories, such as between school subjects or programmes (Bernstein, 2000; Hoadley \& Muller, 2010). According to Bernstein and Solomon (1999), there is always a boundary, although it varies and classification can be strong or weak. Where the classification is strong, entities are kept apart, but brought together in cases of weak classification. Power lies in the gap between categories and preserves the space between them. An example of weak classification is when boundaries between subjects are blurred due to cross-curricular themes.

Bernstein (2000) also developed the concept of framing to focus on communication and control over students' learning, for example, the selection, sequence, pace, and criteria of knowledge. When the framing is weak, students apparently have a greater opportunity to influence their learning; the teacher is in control, however, if the framing is strong.

In addition to the concepts of classification and framing, Bernstein (2000) developed the concepts of vertical and horizontal discourse to distinguish between different forms of knowledge. Horizontal knowledge is segmented and closer to common knowledge, while vertical knowledge is hierarchically structured and identified by specialised language (Bernstein, 2000). Strongly 
classified subjects are usually identified with vertical knowledge structures, in which sequence and conceptual coherence are more important (Muller, 2012).

Bernstein's (2000) theory centres around the role of schools in the reproduction of social inequalities. One important aspect of this is the knowledge roadblocks produced by strong classification of certain subjects. According to Bernstein (1971), curricula usually include assumptions that some areas of knowledge are more worthwhile than others. Scholars have argued that such high status disciplines with vertical knowledge structures are identified with strong classification (Bleazby, 2015) and that classification is especially strong between mathematics and other subjects (Cause, 2010). Research has shown that natural science programmes tend to attract high achieving students from strong social backgrounds (Beach, 2008; Hjelmér, 2011; Weis, Cipollone, \& Jenkins, 2014), and that mathematics in particular is known to be a gatekeeper to higher studies and well paid jobs in society (Arnot \& Reay, 2004; Lynch \& McGarr, 2016; Straehler-Pohl \& Gellert, 2013).

In addition to strong classification, the framing of pacing rules has also been identified as an obstacle to student performance. Pace is indeed the 'economy of the pedagogy' with consequences for social inequality (Bernstein, 1990, p. 76). Research has demonstrated that curricular subjects with vertical knowledge structures need a weaker framing over sequence and pacing to optimise success for all students, particularly those from weaker social backgrounds (Hoadley \& Muller, 2010; Morais \& Neves, 2011; Young \& Muller, 2013). Inter alia, scholars have argued that this is because strong framing of pace requires students to have resources and support from outside the school to maintain the pace (Arnot \& Reay, 2004; Bernstein, 2000), such as private tutors. Furthermore, research has indicated that rather than asking for a slower pace, students drop subjects or programmes if they cannot keep up (Arnot \& Reay, 2004) or their requests for a slower pace are met with indifference (Bjarnadóttir \& Geirsdóttir, 2018; Hjelmér, 2011).

Blöndal, Jónasson, and Tannhäuser (2011) have argued, in the context of high drop-out rates in Icelandic upper secondary schools, that prestigious schools in Iceland do not see it as a problem when students quit academic programmes if they fail to meet the required standards. A recent study by Jóhannesson and Bjarnadóttir (2016) reported that more students have aspirations for a college education than those who are expected to succeed in academic programmes. By enrolling in a school that emphasised different pedagogic practice, without lowering the conceptual demands, students managed to break down the roadblocks they had previously faced.

The current upper secondary school curriculum (Ministry of Education, Science and Culture, 2012) in Iceland presents considerable changes to the organisation of academic programmes, compared to the previous curriculum (Ministry of Education, Science and Culture, 1999), as there are no longer any national programmes. Schools have considerable freedom in organising the content of the curriculum and overseeing what is taught to whom and how. Nevertheless, the curriculum presents previously mentioned fundamental pillars of education that are supposed to guide teachers of all subjects in their work across schools and programmes and contribute to school development. For instance, the funda-mental pillars present a vision for bridge-building through themes and subjects with interdisciplinary methods, involving 'unconventional teaching methods' (p. 15). These changes are in accord with contemporary curricular changes worldwide, in which cross-curricular linkages are emphasised (Lingard \& McGregor, 2014; Lynch \& McGarr, 2016; Whitty, 2012). Such practices entail weaker classification of subjects and often weaker framing of pedagogic practices (Bernstein, 2000).

In relation to these trends towards cross-curricular goals, Hardarson (2010) conducted a study on how teachers of history, mathematics, and natural sciences in Iceland worked with common educational goals, such as democracy, in their pedagogic practice. His results indicated that teachers see themselves first and foremost as subject teachers and that they did not attend specifically to common educational goals in their teaching. They believed that common goals were already automatically approached through subject knowledge and required no changes in their pedagogic 
practice. Another study by Reynisdóttir and Jóhannesson (2013), in which experienced upper secondary school teachers were interviewed about common goals and fundamental pillars, indicated that teachers had not come to terms with the ideas presented in the curriculum. Half of the teachers shared the views found in Harðarson's (2010) study, but others believed that the implementation of the policy required considerable changes of the educational landscape and pedagogic practice (see also Ragnarsdóttir, 2018). These studies indicate that bridge-building across the curriculum is perceived as problematic by the teachers, as subjects tend to be strongly classified. Lynch and McGarr (2016) have argued that the strengthening of subject boundaries through the prioritisation of certain disciplines can hinder cross-curricular collaboration. This particularly applies to subjects with vertical knowledge structures, such as mathematics.

\section{Data and methods}

This article presents an analysis of semi-structured interviews with all of the 16 academic subject teachers who participated in the research project Upper Secondary School Practices: Student Engagement and Initiative (see also Óskarsdóttir, 2018)I. These teachers, who taught at nine different schools, all taught academic subjects. Sometimes, particularly in the smaller schools in the sample, the same teacher taught mathematics, physics, and natural sciences or psychology and sociology. However, the teachers all identified themselves as subject teachers based on their educational background and accordingly I have grouped related subjects together in four categories: languages, social science, natural science, and mathematics. Some teachers belong to more than one group.

Table 1. Number of participants from different subject fields

\begin{tabular}{lc}
\hline Field of subject & Number of participants \\
\hline Languages (Icelandic, English, German, French) & 7 (all female) \\
Social science subjects (sociology, psychology, gender studies) & 2 (1 female, 1 male) \\
Natural science subjects (natural sciences, physics, chemistry) & 3 (2 female, 1 male) \\
Mathematics & 4 (2 female, 2 male) \\
\hline
\end{tabular}

Icelandic, English, mathematics, Danish, and a third language are all common core subjects in academic programmes in the upper secondary school curriculum (Ministry of Education, Science and Culture, 2012), even though both the number of mandatory courses and their content varies between programmes. Advanced social science courses and natural science courses are key subjects of either the social science programme (SSP) or the natural science programme (NSP), although basic courses within both fields are a traditional part of all academic programmes. This explains why there are comparatively more interviewees from languages and mathematics, since those are common core subjects taught across programmes. Four male teachers and 12 female teachers participated in the study. Their teaching experience ranged from one year up to almost 30 years. Two of the schools are selective, academically-oriented grammar schools, while seven are identified as comprehensive schools in which there was more variance in terms of programmes (academic, vocational, arts) and special support for students (lower streaming courses, at least in mathematics, and individual programmes). The grammar schools only offered academic, university-preparatory programmes and enrolled students with above average grades, as they have strong admission requirements and the applications exceed their vacancies. Conversely, the comprehensive schools in the study usually receive fewer applications than the number of places they can offer (Menntamálastofnun, 2017) and their admission requirements are not as strong (Eiríksdóttir et al., 2018).

The focus of the interviews was to discuss the visions the teachers had concerning pedagogic practice, learning, and teaching. For example, teachers' views towards students and their roles and opportunities to influence were discussed. They were asked how they met different needs 
of their students, how students could influence pedagogic practice and show initiative, and what opportunities students had to view their opinions and participate in decision-making. Also, different aspects of the curriculum, assessment practices, and homework were discussed. A group of three researchers were responsible for conducting the interviews, either individually or with other members of a research team, adhering to an interview guide discussed and developed by the team of researchers. Most of the questions were open and threads were followed by probing questions (Brinkmann \& Kvale, 2015). Each interview lasted around 60 minutes and they were recorded and transcribed verbatim. Excerpts were translated from the Icelandic originals into English by the author and then checked by a bilingual proofreader. Participants were assured anonymity so the names of the teachers have been changed to protect their identities. One of the strengths of the data is that the teachers represent different schools and subjects and there is a concentrated sample of both language teachers and mathematic teachers. However, there are only two teachers from social science subjects and three from natural science subjects, which is a limitation of the study.

Before beginning the initial analysis, I listened to all the audio files, read the interviews, and added my own remarks to the files. Then the documents were printed and the analysis was begun, using Braun and Clarke's (2013) steps of thematic analysis which involved reading the interviews carefully more than once, adding comments and writing familiarisation notes to each of them. Then I conducted a complete coding of the data set. The coding process involved reading the interviews a few more times while making exploratory comments and further developing them into codes. All the codes and excerpts from the original data were then collated for similar codes before identifying patterns across the data in relation to student influence and Bernstein's theoretical concepts. The patterns eventually resulted in candidate themes. The three main themes generated from the data will be presented and discussed in the following sections. First, the cases where students had opportunities to influence their learning will be presented. The second section of the findings presents cases of weaker classification of subjects, where bridges are built between subjects involving a stronger position of students. The third section draws out the construction of mathematics as a dividing force between different programmes, exacerbating knowledge roadblocks for students.

\section{Room for influence}

Many of the teachers who described pedagogic practice identified with opportunities for student influence, mainly regarding what and how students learned. The language and social science teachers, both from the grammar and the comprehensive schools, frequently reported that they gradually weakened the framing of content and assessment. Students could choose themes, texts, form of assessment, timing of assessment, or topics within a certain framework provided by the teachers. As an example of a weaker framing of assessment, Jóhanna, an Icelandic language teacher, explained that she allowed her students to choose the projects they wanted her to include in the end of term evaluation: 'They can develop their own portfolio of assignments they want to hand in as a part of their grade'. Similarly, Elín, a psychology teacher, said that students might not be able to control what they learned:

But they often control the outcome or what they want to hand in to me. They usually must hand something in, either orally or slides or short films or something. I usually have some alternatives.

Likewise, María who taught English, explained how her students could often choose articles to read and assignments to complete, within certain criteria set by the teacher:

They become independent in their studies and the teacher is, in fact, a facilitator. He withdraws a bit and tries to train those skills that they need to be able to continue learning through the assignments. 
Anna, a third language teacher, said she wanted students to take more responsibility over their learning. As a way to make students more independent, she often asked them how they would like to learn:

I often ask them, ahh, now we are learning declensions ... "How are you going to learn this?" ... And then they come up with ideas ... I leave it to my student to decide; what would you like? ... We are all so different with regard to what methods fit.

In geology, Guðrún, from a grammar school, and Una, from a comprehensive school, reported how they weakened the framing by allowing students to influence both the content and form of assessment. They did that by allowing individuals to choose some geological phenomenon, such as mountains or earthquakes, to deepen their knowledge and understanding. The students worked with their chosen phenomenon and presented their work in different ways. Una also taught chemistry within the NSP and explained how she also used variety in her teaching methods in that subject by allowing students to influence their learning:

They can have influence in chemistry. I have an assignment where they are supposed to decide for themselves what they want to do, if they want to do experiments or write a paper... [and] they all have something that they find interesting and it can be something fun.

No such examples were found in mathematics. Guðrún taught both natural science subjects and mathematics in a grammar school and reflected on the difference. 'Mathematics is perhaps a little pinned down, what has to be included and there is not much time to do other things'. The strong framing of mathematics was further crystallised in the words of Gunnar, a mathematics teacher in another grammar school:

Students do not control anything, we have full control and I think it is not possible to do this any other way. Of course they ask, "Why do we have to learn all this?" That always happens and there is nothing unusual about it, they cannot change that, naturally.

As the above examples show, it is mostly the language teachers who report that they allow for student influence over how or what they are taught. These are the subjects in which teachers describe a weaker framing of the pedagogic discourse. This was true for language teachers from both types of schools. These results also indicate a strong classification between mathematics and other subjects. These findings are in tune with previous studies; that is, the framing of the pedagogic discourse seems to be stronger within natural science subjects and mathematics (Bjarnadóttir \& Geirsdóttir, 2018; Cause, 2010). According to Bleazby (2015), there are examples of weaker framing in geology and chemistry, because the natural science subjects have a lower status in the subject hierarchy than mathematics, as reflected in a more direct link with the material world.

\section{Online learning platform used as a channel for student influence}

Many of the teachers in the study explained that they had been trying to develop their subjects in the direction of more student-centred approaches, in which student autonomy and influence was emphasised. Such examples were described by teachers from all subjects, except for mathematics. For example, some teachers found the use of student diaries an important way to enhance student voices and feedback. This was often done through an online learning platform, which was also used by teachers to provide a channel through which reticent students could express their opinions.

Elín emphasised this practice among her psychology students, as she did not want them to feel uncomfortable in classes. 'Because you need ... of course we are not all that proficient talking 
and [some] find it uncomfortable talking in the group'. She further explained, 'I let them write into their portfolio after each class, so that, I think it counterbalances. I see that those who do not speak, they are thinking a lot about it'. María also explained how she used the online learning platform for similar purposes in English and identified how she managed to hear from all students through that channel, not just those who are loud and express their opinions in class:

The best thing was that, in the diaries, half of the class was like 'yes, [the book] was great ... it was like this and that'. So I saw that I had to give the book another chance because it was not so bad.

Before asking students to express their opinions in the weekly diary, María had asked students about that particular book in class, and a few outspoken students had expressed their discontent. María was well aware of the importance of providing this channel for all students to feel comfortable expressing their voices.

[The English language teachers'] idea is that [students] have a platform there. They get used to expressing their opinions. Some find it difficult to share personal things. And because there, they have a channel .... and I reply. There is a direct connection to the teacher ... they might not feel like coming up to me and telling me, but they feel like they can write it.

In these examples, Elín and María, who both taught in comprehensive schools, explained how they consciously used the online learning platform to hear from silent students and enhance everyone's voices. They did that because they were both aware that some students find it difficult to express themselves in lessons. This is an example of an approach where the framing of studentteacher communication has been weakened and traditional power structures challenged, resulting in the creation of voices through pedagogies (Arnot \& Reay, 2007). Therefore, it is not only the students who feel comfortable expressing themselves in front of others that can influence pedagogic practice. Drawing on Fleming's (2015) argument, student voice must be viewed in the context of power by asking who is listening and who has a voice.

Although not all teachers reported using student diaries as purposefully as Elín and María, it seemed to be a rather ordinary practice among language teachers. The teachers who taught integrated courses also described how they used weekly student reports to ask for their opinions regarding the teaching content. Students were often asked how they liked the books they were supposed to read and the teachers said that they made changes accordingly. Like Jóna, an English language teacher said:

We get their opinions and if we hear too much that a book is boring, as sometimes happens, the boys find some book boring, we rush to change. We listen a lot to them, if it appeals to them.

It is important to highlight the different approaches by María and Jóna, two English teachers from distinctive schools. They both explained that they wanted to listen to students and adhere to students' wishes concerning the teaching material in their subject. However, they followed two different paths. One path does not challenge power structures in the classroom (Arnot \& Reay, 2007; Baroutsis, McGregor, \& Mills, 2015), as Jóna listens to the loudest students and makes changes accordingly. Maria, to the contrary, deliberately creates a channel for all students to express their opinions and influence decisions. 


\section{Influence towards non-learning}

Student influence, as described by the teachers in the study, was not limited to methods intended to enhance students' learning or interests. Students also influenced practice that can be said to contribute to their non-learning or the lowering of conceptual demands (see e.g. Morais \& Neves, 2016). For example, many of the teachers, from both school types, explained that it was nearly impossible to expect students to do any homework. As a result, many teachers had stopped anticipating that homework would be completed and those who still did said they had to make sure it was interesting. Sara, a third language teacher in a grammar school, found this problematic. 'I feel like they do less of it since I started [teaching]. Even though they are not overburdened with homework, they still tend to skip it.' She had changed her course and tried to find 'fun' projects for students to do at home:

$[R]$ ather than some grammar practices ... I assigned them the task ... of finding a musician that they liked. And then it was easy to do the homework.... Then they are on YouTube and that is easier than an assignment.

In the above example, Sara explained how the little homework she demanded of her students was easy and somewhat perceived as a non-assignment. Previous studies have addressed the problematic role of the 'edutainer', or a teacher who is afraid of losing students' interest and consequently reduces content or lowers demands (Arnot \& Reay, 2004; Hjelmér \& Rosvall, 2016). This view was crystallised in the words of Kristín, an English language teacher, when she said, 'Most of the students are willing to do something if you just make things exciting enough. There is sometimes this demand ... I mean, we are not always entertainers'.

Kristín had abandoned homework for the most part. '[T]o activate them to do something at home, remember something or read a book at home is so much more difficult'. Anna responded similarly, 'Homework has somewhat, it has just turned out that the half, scarcely half of the student group has completed [it]. So therefore I assign less and less homework'. Kristín also explained the importance of giving students time to work on group assignments in lessons, something that she could expect them to do outside school hours some years ago. 'Work outside class is the most difficult thing nowadays. You hardly create a group assignment that they cannot complete in lessons'.

Una was having trouble finding good teaching material in Icelandic in her natural science subjects, particularly in chemistry. She wanted to use books in English, but said 'experience has taught me that students do not read the books if they are in English. They just say that they do not understand and will not even try'. Una therefore let her NSP students influence the choice of teaching material, even if it meant that she had to choose material that she found outdated and not good enough.

The comprehensive upper secondary schools in Iceland usually offer lower streaming courses for those who complete lower-secondary schools with 4.5-6.5 points out of 10 in mathematics. The idea is to slow the pace for this group, meaning that students have three semesters to complete six credits in basic mathematics while the norm is two semesters (Bjarnadóttir, 2011). Katrín taught mathematics in one of those lower streaming groups and explained how she sometimes sensed that her students were tired and did not feel fit for her lessons. They also protested at times when she wanted them to do group work. In both cases, students' reluctance made Katrín change her plans. The weak framing of mathematics courses allowed students to influence her teaching methods. Lóa described similar events. She taught a basic mathematics course that was a part of the social science programme in her school. She had been experimenting with flipped learning, in which she would record videos that she expected her students to watch at home between lessons. However, only some of her students did this, creating the need for Lóa to repeat the briefings in lessons as well. Her extra work, intended to help students gain a better understanding and preparation for classes, was ignored by most of the students without negative consequences. 
The weak framing of pace in these mathematics courses for the lower streaming and SSP students allowed Katrín and Lóa to slow down and adapt to students' implicit targets for influence.

According to Bernstein (2000), there is always pressure to weaken the framing of pedagogic discourse. However, if changes are made, leading to greater student influence, e.g. slower pace or reduction of content, the reasons must be clear. Weaker framing might not be of benefit to students, particularly those with less support from home (see e.g. Morais \& Neves, 2016; Smyth, 2016). Weaker framing can result in some students losing out on important knowledge or in the creation of roadblocks in terms of access to further education. Students with a strong social background find other ways to secure educational advantages. For example, a recent study from Australia reported that middle class parents responded to weaker framing of pedagogic discourse by paying for supplementary, private tutoring (Sriprakash, Proctor, \& Hu, 2016).

\section{Breaking the walls: Teamwork and integration of subjects}

Many of the teachers described close cooperation with colleagues from different subjects and some had recently taken part in developing integrated courses, in which teams of teachers worked closely together across subject fields. That development was in the wake of the current curriculum (Ministry of Education, Science and Culture, 2012). For example, Jóna, an English language teacher in a grammar school, said that the teachers in her department taught two integrated courses. She taught a course that combined English, history, and sociology, in which the focus was on the development and history of a foreign country. Other language teachers from Jóna's school also worked together in another integrated subject, in which teachers from all the five languages taught at the school played a role. Similarly, Sara, a third language teacher from another grammar school, described a long tradition of integrated courses, both across languages as well as in collaboration with teachers within the field of geology and IT. According to Sara, the school leaders supported this kind of development, for example, by facilitating and paying for weekly team meetings. One of the advantages of this kind of pedagogic practice, according to Sara, was that the teachers 'all had different strengths' to support the collaboration.

Jóhann is a sociology teacher who also taught an integrated course with a team of other teachers. Like Sara, he explained how collaboration with different teachers supported his professional development:

[The course] is interdisciplinary and ... it is very rewarding for teachers to teach this course. I am teaching with different people; we are five together. There are [five different subjects] and it is all together in one mix. And, you gain a lot from learning from others, both older and younger... [you] develop ideas.

Guðrún taught natural sciences in an integrated course organised with teachers from different natural science subjects and mother tongue teachers. 'I find this idea really interesting, to try to combine these subjects and try to put things in context somehow'. Guðrún explained how the aims of the course focused on students' learnability instead of being organised around specific areas of knowledge. That sometimes confused the students, since they were used to other kinds of pedagogic practice. "They feel a little like they are not doing anything. Sometimes they ask, "When do we start to learn something?" Because it is so different'. The integrated subjects seemed to share the fact that students had considerable influence over their learning and their opinions were considered. As Jóhann said, '[Students] write weekly reports where they can bring their own ideas; they can tell us what they learnt . . . [and] what they did not like as much. So, they can have influence in that way.' Guðrún supported this view and said, 'The teachers are always re-evaluating and changing and improving the course'.

Guðrún also taught mathematics, a subject that she experienced very differently from this integrated course. She described mathematics as a 'deep-rooted' subject, in which teaching 
practices are controlled by strong traditions and monotonous teaching methods. While she was pleased with the work she was doing in the integrated course, and thought it was a 'step in the right direction', she felt it was difficult to change things in mathematics. Guðrún's experience represents the strong classification (Bernstein, 2000) of mathematics from other subjects in her school. While the general natural science subjects build bridges to other subjects, mathematics is walled in.

Jóhanna and Anna came from the same comprehensive school and both taught languages, Icelandic and a third language. Jóhanna told us the teachers in her school had not yet developed an integrated course, but were aware of the development moving in that direction. Supporting that, Anna said the teachers in her department were thinking about how to 'develop, either an international programme or connect tourism studies, languages . . or something, you know, whatever, what we can do to increase interest'.

It is interesting that most subject fields within the grammar schools in the study have participated in the development of integrated subjects: languages, social sciences, and natural sciences. However, none of the interviewees described such development within mathematics. As studies have shown that mathematics is traditionally the subject that has the clearest boundaries, and is identified as strongly classified (Bernstein, 2000; Cause, 2010; Straehler-Pohl \& Gellert, 2013), this is not surprising. Furthermore, Bleazby (2015) has argued that the integration of different subjects and the implementation of cross-curricular themes has failed to deconstruct the traditional curriculum hierarchy, since integrated subjects shift to a lower position within the subject hierarchy. Similarly, the students in Beach's (2008) study felt as if they were not learning anything when boundaries were blurred and the framing weakened. This was reflected in Guðrún's words, when she described how conceptual demands are lowered and more focus is put on students' learnability and skills, causing students to feel like they are not learning anything. Beck (2013) has argued that while this kind of education should be one of the most important educational aims, it is a challenge to get students to take this non-traditional learning seriously.

Unlike the previously described examples, the mathematics teachers in the grammar schools seemed to deviate from this recent curriculum development in their schools, leading to an even stronger classification of mathematics. Studies have shown that students (Beach, 2008) and teachers (Beck, 2013) in some subjects, particularly those which are strongly classified and have a strong performativity culture, find it problematic to sacrifice any time from the timetable for cross-curricular work or wider education aims. This is reflected in Gunnar's words, who finds it annoying that he must give up mathematics lessons due to students' educational trips or extracurricular work:

I find it unnecessary to transfer some parts of the social life into the studies ... I do not want to give up mathematics lessons because students need to do something else.

While previous Bernsteinian studies have shown that strong classification of subjects can result in knowledge roadblocks for students or act as gatekeepers to higher studies, weaker boundaries also need consideration. For example, Morais and Neves (2011) have not been able to show that weaker boundaries between subjects benefit the learning of disadvantaged students. Further studies are needed on the matter, as previous studies have underscored the importance of strongly framed evaluative criteria and strong framing over the selection and sequence of knowledge (Arnot \& Reay, 2004; Hoadley \& Muller, 2010; Morais, 2002; Morais \& Neves, 2011). When those elements of the pedagogic discourse are strongly framed, students know what is expected of them.

Furthermore, scholars have addressed the issue of powerful knowledge in this context. Even though cross-curricular subjects or theme-based curricula seem to be more socially progressive than traditional subject-based curricula, the weakening of boundaries between school curriculum and everyday life could very well deny disadvantaged groups access to the knowledge that builds bridges to further education (Whitty, 2012; Young \& Muller, 2013). 


\section{Mathematics as a dividing force}

Mathematics was the only subject where teachers' responses reflected that the perceived ability of students was strongly related to the programme students chose to attend. A strong classification was identified between mathematics courses within different programmes, for example, the opportunities students had to influence their studies as described by the teachers.

Gunnar taught in a selective grammar school that only accepts students with good grades in all subjects, irrespective of which academic programme they choose. Still, Gunnar represents a vision where students' choice of programme is defined by their mathematics skills, as he claimed that students' mathematics ability depended on the programme in which they were enrolled:

We, the mathematics teachers, we of course find a lot of difference between the programmes. There is of course a lot of difference in how they fare in mathematics, depending on whether they have chosen to enrol in the natural science programme or not, or some of the other programmes.

Guðrún told a similar story. She taught SSP students mathematics, in another grammar school that only enrols academically strong students. She said:

$[B]$ ecause I have the social science programme classes and they are not that interested and it is a little bit difficult to, yes, to motivate them. Or, some, some are excited and enjoy it.

This stereotypical notion of how students other than those who choose the NSP programme, lack the skills and motivation to succeed in mathematics, was noticed by other teachers. Nói, who taught mathematics and natural sciences in a comprehensive school, said, 'The thing with many students in the SSP programme is that they have a phobia for natural sciences'. He also identified some of his students as 'slouches', meaning that they were trying to make things as easy for themselves as possible. 'That is more in [courses for other students than from the NSP programme]'. This idea is problematic, i.e. that the ability to succeed in learning mathematics is restricted to the students who choose the NSP, because it has been found to lower the motivation of other students (see e.g. Jonsson \& Beach, 2017; Mazenod et al., 2018).

When Gunnar described his teaching in a mathematics course for the SSP students, he said, "We do not go into depth in the mathematics behind [the tasks]. This is a mandatory course for the SSP students'. He also explained that there was leeway to reduce some of the content in mathematics for the SSP students. "We decided because this is the part that has been a hindrance for those who are struggling with mathematics'. Similarly, for Katrín, a teacher in a lower streaming mathematics course, it seemed to be the norm that students from the SSP could not cope with the mainstream mathematics courses, as reflected in her words:

A large part of the group are students from the social science programme and [a vocational programme], because this was the lower streaming ... a large majority of the natural science programme students go directly to [the general mathematics course].

To help her students pass the mathematics exam, Katrín helped them decide how much of the syllabus they could skip without failing, 'so I am actually reducing, excluding the most difficult parts so they at least get the fundamental things and a little bit more than that'. This was her way to allow students to influence their mathematics education. Studies have pointed to the need to problematise the nature of the learning support students are offered within different programmes in the upper secondary schools. The intended support, such as reducing content, as done by both Gunnar and Katrín, can reinforce existing social differentiation (see e.g. Mazenod et al., 2018; Johansson, 2017). 
Jónas taught mathematics both to NSP students and lower stream students. He described how the pace was much stronger in mathematics courses for the NSP students, even far too accelerated. 'The third course was terrible . . way too much content, nonsense . . you run and no one can keep up'. It was not possible for students in the NSP to influence the pacing, according to Jónas. It can be understood from his words that he feels powerless against the external control of the syllabus. However, Jónas explained that it was different in the lower streaming course:

There is variance in the pace, but that is all right. This course is roomy enough so that you do not feel any pressure ... [this is] a course where we are quite free.

Students' choice of programme also influenced whether or not they had to do homework. Gunnar said, 'We demand homework from the NSP students. It is just because we have to do that. They have to do more than just what is done in classes'. The pace was too high for students to be able to complete all their work in school. This is in accord with previous studies, in which the problem of strong pace has been addressed (Arnot \& Reay, 2004, 2007; Bernstein, 2000; Hjelmér, 2011; Hjelmér \& Rosvall, 2016). Not all students have access to help at home or financial support to pay for private tutoring. However, previous research has shown that students frequently seek private tutoring (Bray, 2007). Students in some selective Icelandic grammar schools have reported that it seems to be a matter of course to seek supplementary tutoring to be able to complete strongly framed NSP mathematics courses (Bjarnadóttir \& Geirsdóttir, 2018; Bjarnadóttir, Öhrn, \& Johansson, 2018).

The reason for not demanding homework of other students was, according to Gunnar, that the NSP students simply have to put more work into their mathematics studies due to high pace and because 'homework does not help [the SSP students] as much as [the NSP students] because they just need more help with their tasks'. Hence, another reason for not requesting homework of the SSP students was due to their lack of ability to work independently. While Gunnar said that he and his fellow mathematics teachers had room to reduce the content and slow down the pace in the general mathematics courses for the SSP students, they could not do that in courses taken by the NSP students. According to Gunnar, the grammar school in which he worked emphasised good preparation for a university education. Part of the reason for the strong pacing in mathematics in the NSP was related to demands from the university:

You know for example that certain departments in the University of Iceland emphasise that students have covered ... certain content.

This divide in demands towards these two academically strong student groups in Gunnar's grammar school shows the strong classification of mathematics courses within the NSP and how high the barriers are for those wishing to gain that knowledge. It is not for everyone to cope with, although it is assumed that the NSP students can manage the strong pace and complete their homework without the help of their teachers. The strong classification is also mirrored in the fact that the external demands from the university level only reach the natural science students.

In the above examples, a stereotypical notion emerges as to who has the ability to succeed in mathematics. The teachers' descriptions reflect a divide in terms of expected ability between NSP students and all other students, even in the most selective schools in the study. Studies from the Nordic countries have shown that there is a trend towards a strong divide between the perceived ability of students from vocational programmes and other programmes to acquire disciplinary knowledge, demonstrating low expectations towards vocational students (Nylund et al., 2018). According to Hjelmér and Rosvall (2016), teachers 'had difficulties in picturing vocational students as ambitious and high achievers in mathematics' (p. 14). Similarly, academic students have negative class stereotypes towards vocational students (Jonsson \& Beach, 2015). Drawing on Beck (2013), these attitudes are important in the reproduction of existing 'hierarchies of social classes'. The data presented in this study suggest that we also need to look at the strong classification between the NSP and other academic programmes, such as the social science 
programme, as it is problematic if students' choice of programme determines the expectations about their ability to succeed in certain subject areas.

\section{Concluding remarks}

This study has presented results indicating an upper secondary school system where mathematics is strongly classified, while teachers from other subjects have moved towards more teamwork and integration, allowing more room for student influence. However, the study also indicates that student influence is not always of benefit to their education and that the apparently weaker framing of some subjects needs to be considered.

The strong classification of mathematics particularly applies to the natural science programme, whose courses are identified with a strong framing of the pedagogic discourse. This is especially relevant to the grammar schools in the study. Students enrolled in other programmes are perceived by the mathematics teachers as lacking the ability to succeed in mathematics. Drawing on Valero (2006), students' engagement with learning mathematics must be viewed in a wider context. Instead of seeing this as an individual matter, she discusses the need to look at the position of mathematics in a social, cultural, and political context. The findings of this study mirror stereotypical notions of students' capacity and interest in certain subjects, underpinning the importance of addressing the political context of subject hierarchies.

The results highlight the strong status of mathematics within the natural science programme, particularly within the grammar schools in the study, as its vertical knowledge structure acts as a gatekeeper for those who cannot keep up with the strong pace. Bernstein and Solomon (1999) have emphasised that for some of those students such boundaries do not matter much, as they may have resources outside of school to deal with them, but for others it is a narrow path. As an implication, pedagogic practices should pay more heed to differences in terms of the time needed by students to study the subject.

Teachers from languages, social science and natural science courses describe inclusive and flexible practices, identified with a weak framing of the pedagogic discourse in which there is greater leeway for student influence. That is reflected in, for example, the development of integrated courses and collaboration between subjects. On the other hand, mathematics has responded to different needs of students by lowering the conceptual demands within programmes other than the natural science programme, thereby depriving them of powerful subject knowledge (Morais \& Neves, 2016; Whitty, 2012; Young \& Muller, 2013). Bleazby (2015) argues that endeavours to break down subject hierarchies have failed. Attempts to build bridges between subjects result in subjects at the top of the hierarchy being further walled in since they do not participate in the development. This seems to have happened in mathematics within the natural science programme in Iceland.

Achievement in mathematics is the key to many university programmes within the field of natural sciences and technology, since it is one of the core subjects within the natural science programme. Therefore, the strong classification and framing of mathematics within the NSP can close the doors for many students who aspire to future studies within the field of natural sciences. Ball (2016) claims that educational policy has (unintentionally) reproduced the relationship between opportunity, achievement and social class. The current upper secondary school curriculum (Ministry of Education, Science and Culture, 2012), where academic programmes can vary between schools, possibly causing stronger classification between schools, subjects, and programmes, needs to be considered in that context. 


\section{Note}

I The data consist of 130 classroom observations; over 60 transcribed interviews with students (group interviews), teachers and school administrators; photographs of classrooms; syllabi; and other written records. Fifteen researchers from the School of Education and School of Social Sciences in the University of Iceland participated in data collection. The research project received a grant from the University of Iceland Research Fund 2013-2015 and from the NordForskfunded Nordic Centre of Excellence: Justice through education in the Nordic countries 20132018. Our special thanks to the upper secondary schools that provided us with access to data. 


\section{Að byggja brýr og reisa veggi: Stigveldi námsgreina í ljósi viðhorfa framhaldsskólakennara til nemendaáhrifa}

Баð er gömul saga og ný að framtíðarmöguleikar og tækifæri ungs fólks byggist gjarnan á námsvali pess. Í pví samhengi hefur stigveldi starfs- og bóknáms verið til umræðu (sjá t.d. Niemi og Rosvall, 2013; Nylund o.fl., 2018; Sych, 2016) en jafnframt hefur komið í ljós að ekki nýtur allt bóknám sömu virðingar í samfélaginu. Dannig hafa rannsóknir gefið til kynna að náttúrufræðibraut sé sú braut sem laðar að sér námslega sterka nemendur úr efri lögum samfélagsins (Beach, 2008; Bleazby, 2015; Weis, Cipollone og Jenkins, 2014) og að árangur í stærðfræði greiði götu ungs fólks að vel launuðum störfum í framtíðinni (Arnot og Reay, 2004; Lynch og McGarr, 2016; Straehler-Pohl og Gellert, 2013). Á sama tíma hefur bæði alljóðleg og íslensk menntaorðræða og skilgreind pólitísk stefna í meiri mæli einkennst af áherslu á nemendamiðað nám og tækifæri nemenda til að hafa áhrif á nám sitt (Arnesen, Lahelma, Lundahl og Öhrn, 2014; Ministry of Education, Science and Culture, 2012).

Dví er fróðlegt að skoða hvort og hvernig virðingarröð bóknámsgreina endurspeglast í viðhorfum framhaldsskólakennara til nemendaáhrifa. Sérstök áhersla er lögða að draga fram viðhorf og sýn kennara úr mismunandi námsgreinum og af ólíkum brautum. Byggt er á viðtölum við 16 framhaldsskólakennara úr ólíkum framhaldsskólum sem allir eiga pað sameiginlegt að kenna bóknámsgreinar á stúdentsprófsbrautum. Kenningalegur bakgrunnur greinarinnar byggist á kenningu Basil Bernsteins (2000) um félagsfræði menntunar.

Niðurstöðurnar sýna hvernig hugmyndir kennara um áhrif nemenda í ólíkum námsgreinum styðja við og viðhalda hefðbundinni stöðu greina. Svigrúm virðist til að fækka efnispáttum og fara hægar yfir í stærðfræði á öðrum brautum meðan mikil festa er í hraða yfirferðar og inntaki í stærðfræði á náttúrufræðibrautum. Рað sem virðist ekki síst ráđa pessu eru fyrir fram mótaðar hugmyndir um skort á getu og áhuga nemenda af öðrum brautum á að læra stærðfræði. Kennarar í öðrum námgreinum en stærðfræði lýsa jafnframt kennsluaðferðum og skipulagi sem felur að einhverju leyti í sér tækifæri fyrir nemendur til að hafa áhrifá pað hvað og hvernig peir læra. Pau áhrif eru mismikil og fela jafnvel í sér ógn við sett námsmarkmið. Sterk og óbreytanleg staða stærðfræðinnar er jafnframt enn greinilegri í ljósi pess hvernig brýr hafa verið byggðar og samfagleg vinna aukin í tungumálum, félagsgreinum og raungreinum.

Dessar niðurstöður endurspegla íslenskan framhaldsskóla par sem væntingar til námsgetu nemenda ráđast af vali peirra á brautum. Dar sem skipulag stærðfræðiáfanga á náttúrufræðibraut einkennist af hraðri yfirferð, sem ekki allir ráða við, má segja að greinin pjóni hlutverki hliðvarðar, meðal annars fyrir pá nemendur sem hafa hug á raunvísindanámi. Greinin getur pannig verið umtalsverð hindrun á leið nemenda til brautskráningar af náttúrufræðibraut og jafnframt til frekari menntunar, bæði par sem formlegar kröfur eru um undirbúning í raungreinum en jafnframt par sem undirbúningur í raungreinum og stærðfræði er mikilvægur. Einnig er hætta á pví að nemendur annarra brauta fari á mis við almenna menntun ef svigrúm til áhrifa er of mikið og ákvarðanir um inntak náms byggjast á fyrir fram gefnum hugmyndum um skort á námsgetu.

Lykilorð: Framhaldsskólar, nemendaáhrif, stigveldi námsgreina, orðræða uppeldis og kennslu, pekkingartálmun 


\section{Um höfundinn}

Valgerður S. Bjarnadóttir (vsb1@hi.is) er doktorsnemi við Menntavísindasvið Háskóla Íslands. Hún hefur lokið B.A.-prófi í uppeldis- og menntunarfræði og kennslufræði til kennsluréttinda frá Háskóla Íslands og meistaraprófi í alpjóðamenntunarfræðum frá Stokkhólmsháskóla.

\section{About the author}

Valgerður S. Bjarnadóttir (vsb1@hi.is) is a doctoral student in the School of Education at the University of Iceland. She holds a B.A. degree in Education, a teaching degree from the University of Iceland and an M.Sc. in International and Comparative Education from Stockholm University.

\section{References}

Arnesen, A.-L., Lahelma, E., Lundahl, L., \& Öhrn, E. (2014). Unfolding the context and the contents: Critical perspectives on contemporary Nordic schooling. In A.-L. Arnesen, E. Lahelma, L. Lundahl, \& E. Öhrn (Eds.), Fair and competitive? Critical perspectives on contemporary Nordic schooling (pp. 1-22). London:The Tufnell.

Arnot, M., \& Reay, D. (2004). The framing of pedagogic encounters. In J. Muller, B. Davies, \& A. Morais (Eds.), Reading Bernstein, researching Bernstein (pp. 137-150). London: Routledge Falmer.

Arnot, M., \& Reay, D. (2007). A sociology of pedagogic voice: Power, inequality and pupil consultation. Discourse: Studies in the Cultural Politics of Education, 28(3), 311-325. doi:10.1080/01596300701458814

Ball, S. (2016). Education, justice and democracy: The struggle over ignorance and opportunity. In A. Montgomery, \& I. Kehoe (Eds.), Reimagining the purpose of schools and educational organisations (pp. 189-205). Cham: Springer.

Baroutsis, A., McGregor, G., \& Mills, M. (2015). Pedagogic voice: Student voice in teaching and engagement pedagogies. Pedagogy, Culture and Society, 24(1), 123-140. doi:10.1080/14681366.2015.1087044

Beach, D. (2008). The paradoxes of student learning preferences. Ethnography and Education, 3(2), 145-159. doi:10.1080/17457820802062375

Beck, J. (2013). Powerful knowledge, esoteric knowledge, curriculum knowledge. Cambridge Journal of Education, 43(2), 177-193. doi:10.1080/0305764X.2013.767880

Bernstein, B. (1971). Class, codes and control, Vol. I. London: Routledge \& Kegan Paul.

Bernstein, B. (1990). Class, codes and control, Vol. IV:The structuring of the pedagogic discourse. London: Routledge.

Bernstein, B. (2000). Pedagogy, symbolic control and identity: Theory, research, critique (Revised edition). Boston: Rowman \& Littlefield.

Bernstein, B., \& Solomon, J. (1999). 'Pedagogy, identity and the construction of a theory of symbolic control': Basil Bernstein questioned by Joseph Solomon. British Journal of Sociology of Education, 20(2), 265-279. doi:10.1080/01425699995443

Bjarnadóttir, K. (2011). Stærðfræði 102 í fjölbrautaskóla.Vandi og ávinningur [Mathematics for all. Problems and advantages of comprehensive schools]. Netla - Veftímarit um uppeldi og menntun [Netla - Online Journal on Pedagogy and Education]. Retrieved from http://netla.hi.is/greinar/2011/ryn/008.pdf

Bjarnadóttir,V.S., \& Geirsdóttir, G. (2018). 'You know, nothing changes'. Students' experiences in influencing pedagogic practices in various upper secondary schools in Iceland. Pedagogy, Culture and Society. doi:10.1 080/14681366.2018.1439995

Bjarnadóttir,V. S., Öhrn, E. and Johansson, M. (2018). Pedagogic practices in a deregulated upper secondary school: A study of upper secondary school students' attempts to influence their everyday schooling. Manuscript submitted for publication.

Bleazby,J. (2015). Why some school subjects have a higher status than others:The epistemology of the traditional curriculum hierarchy. Oxford Review of Education, 41(5), 671-689. doi:10.1080/03054985.2015.1090966

Blöndal, K. S., Jónasson, J. T., \& Tannhäuser, A.-C. (2011). Dropout in a small society: Is the Icelandic case somewhat different? In S. Lamb, E. Markussen, R. Teese, N. Sandberg, \& J. Polesel (Eds.), School dropout and completion: International comparative studies in theory and policy (pp. 223-251). London: Springer. 
Braun,V., \& Clarke,V. (2013). Successful qualitative research. A practical guide for beginners. London: Sage.

Bray, M. (2007). The shadow education system: Private tutoring and its implications for planners (Second edition). Paris: UNESCO: International Institute for Educational Planning.

Brinkmann, S., \& Kvale, S. (2015). InterViews: Learning the craft of qualitative research interviewing (Third edition). Los Angeles: SAGE.

Cause, L. (2010). Bernstein's code theory and the educational researcher. Asian Social Science, 6(5), 3-9. doi:10.5539/ass.v6n5p3

Eiríksdóttir, E., Ragnarsdóttir, G., \& Jónasson, J. T. (2018). Pversagnir og kerfisvillur? Kortlagning á ólíkri stöðu bóknáms- og starfsnámsbrauta á framhaldsskólastigi [Paradoxes and system errors? The contrasting status of academic and vocational education in the upper secondary school]. Netla - Veftimarit um uppeldi og menntun: Sérrit 2018 - Framhaldsskólinn í brennidepli [Netla - Online Journal on Pedagogy and Education]. University of Iceland, School of Education. Retrieved from http://netla.hi.is/serrit/2018/ framhaldskolinn_brennidepli/07.pdf

Fleming, D. (2015). Student voice: An emerging discourse in Irish education policy. International Electronic Journal of Elementary Education, 8(2), 223-242.

Harðarson, A. (2010). Skilningur framhaldsskólakennara á almennum námsmarkmiðum [How teachers in secondary schools understand the aims of education]. Tímarit um menntarannsóknir [Journal on Educational Research], 7, 93-107.

Hjelmér, C. (2011). Collective actions in the natural science programme. In E. Öhrn, L. Lundahl, \& D. Beach (Eds.), Young people's influence and democratic education. Ethnography studies in upper secondary schools (pp. 34-51). London: The Tufnell.

Hjelmér, C., \& Rosvall, P.-Å. (2016). Does social justice count? 'Lived democracy' in mathematics classes in diverse Swedish upper secondary programmes. Journal of Curricular Studies. doi:10.1080/00220272.20 16.1138326

Hoadley, U., \& Muller, J. (Eds.). (2010). Codes, pedagogy and knowledge. Advances in Bernsteinian sociology of education. New York: Routledge.

Jóhannesson, I.Á., \& Bjarnadóttir,V. S. (2016). Meaningful education for returning-to-school students in a comprehensive upper secondary school in Iceland. Critical Studies in Education, 57(1), 70-83. doi:10.108 0/17508487.2016.1102754

Johansson, M. (2017). Social inequalities in the allocation of learning support in a Swedish upper secondary school. Education, Citizenship and Social Justice, 12(1), 63-74. doi:10.1177/1746197916683467

Jonsson, A.-C., \& Beach, D. (2015). Institutional discrimination: Stereotypes and social reproduction of "class" in the Swedish upper-secondary school. Social Psychology Education, 18, 703-717. doi:10.1007/ s11218-014-9279-1

Jonsson,A.-C., \& Beach, D. (2017).The influence of subject disciplinary studies on students' implicit theories of intelligence and achievement goals in one Swedish upper-secondary school. Education Inquiry, 8(1), 50-67. doi:10.1080/20004508.2016.1275182

Lingard, B., \& McGregor, G. (2014). Two contrasting Australian curriculum responses to globalisation:What students should learn or become. The Curriculum Journal, 25(1), 90-110. doi:10.1080/09585176.2013.872048

Lundahl, L. (2014). Challenges of educational theory in the age of knowledge capitalism. In G. Biesta, J.Allan, $\&$ R. Edwards (Eds.), Making a difference in theory. The theory question in education and the education question in theory (pp. 31-44). London: Routledge.

Lynch, R., \& McGarr, O. (2016). Negotiating subject hierarchies: Neoliberal influences on the comprehensive curriculum in Ireland. Educational Policy, 30(5), 721-739. doi:10.1177/0895904814550077

Mazenod, A., Francis, B., Archer, L., Hodgen, J., Taylor, B., Tereshchenko, A., \& Pepper, D. (2018). Nurturing learning or encouraging dependency? Teacher constructions of students in lower attainment groups in English secondary schools. Cambridge Journal of Education. Advance online publication. doi:10.1080/030576 4X.2018.1441372

Menntamálastofnun [Directorate of Education]. (2017). Innritun í framhaldsskóla lokið [Enrolment to upper secondary schools completed]. Retrieved from https://mms.is/frettir/innritun-i-framhaldsskola-lokid 
Ministry of Education, Science and Culture. (1999). Aðalnámskrá framhaldsskóla [National curriculum guide for upper secondary schools, general section]. Reykjavík: MoESC.

Ministry of Education, Science and Culture. (2012). The Icelandic national curriculum guide for upper secondary schools: General section. Reykjavík: MoESC.

Morais, A. M. (2002). Basil Bernstein at the micro level of the classroom. British Journal of Sociology of Education, 23(4), 559-569. doi:10.1080/0142569022000038413

Morais, A. M., \& Neves, I. P. (2011). Educational texts and contexts that work. Discussing the optimization of a model of pedagogic practice. In D. Frandji, \& P.Vitale (Eds.), Knowledge, pedagogy and society. International perspectives on Basil Bernstein's sociology of education (pp. 191-208). London: Routledge Taylor \& Francis Group.

Morais, A. M., \& Neves, I. P. (2016).Vertical discourses and science education. In P.Vitale, \& B. Exley (Eds.), Pedagogic rights and democratic education. Bernsteinian explorations of curriculum, pedagogy and assessment (pp. 174-191). London: Routledge.

Muller, J. (2006). On the shoulders of giants: Verticality of knowledge and the school curriculum. In R. Moore, M.Arnot, J. Beck, \& H. Daniels (Eds.), Knowledge, power and educational reform. Applying the sociology of Basil Bernstein (pp. 11-27). London: Routledge.

Muller, J. (2012). Forms of knowledge and curriculum coherence. In H. Lauder, M. Young, H. Daniels, M. Balarin, \& J. Lowe (Eds.), Educating for the knowledge economy? Critical perspectives (pp. 114-138). London: Routledge.

Niemi, A.-M., \& Rosvall, P.-Å. (2013). Framing and classifying the theoretical and practical divide: How young men's positions in vocational education are produced and reproduced. Journal of Vocational Education and Training, 65(4), 445-460. doi:10.1080/13636820.2013.838287

Nylund, M., Rosvall, P.-Å., Eiríksdóttir, E., Holm, A.-S., Isopahkala-Bouret, U., Niemi, A.-M., \& Ragnarsdóttir, G. (2018). The academic-vocational divide in three Nordic countries: Implications for social class and gender. Education Inquiry, 9(1), 97-121. doi:10.1080/20004508.2018.1424490

Nylund, M., Rosvall, P.-Å., \& Ledman, K. (2017). The vocational-academic divide in neoliberal upper secondary curricula: The Swedish case. Journal of Education Policy, 32(6), 788-808. doi:10.1080/02680939. 2017.1318455

Óskarsdóttir, G. G. (2018). Starfshættir í framhaldsskólum:Aðdragandi og framkvæmd rannsóknar 2012-2018. Netla - Veftímarit um uppeldi og menntun: Sérrit 2018 - Framhaldsskólinn í brennidepli [Netla - Online Journal on Pedagogy and Education]. University of Iceland, School of Education. Retrieved from http://netla. hi.is/serrit/2018/framhaldskolinn_brennidepli/01.pdf

Ragnarsdóttir, G. (2018). School leaders' perceptions of contemporary change at the upper secondary school level in Iceland. Interaction of actors and social structures facilitating or constraining change (Doctoral dissertation). University of Iceland, Reykjavík.

Reynisdóttir,Á. H., \& Jóhannesson, I.Á. (2013). Fleiri vindar blása.Viðhorf reyndra framhaldsskólakennara til breytinga í skólastarfi 1986-2012 [Increasing changes and challenges: School development 1986-2012 in the eyes of experienced upper secondary school teachers]. Netla-Veftímarit um uppeldi og menntun [NetlaOnline Journal on Pedagogy and Education]. Retrieved from http://netla.hi.is/greinar/2013/ryn/006.pdf

Smyth, E. (2016). Students' experiences and perspectives on secondary education: Institutions, transitions and policy. London: Palgrave Macmillan.

Sriprakash, A., Proctor, H., \& Hu, B. (2016).Visible pedagogic work: Parenting, private tutoring and educational advantage in Australia. Discourse: Studies in the Cultural Politics of Education, 37(3), 426-441. doi:10 .1080/01596306.2015.1061976

Straehler-Pohl, H., \& Gellert, U. (2013). Towards a Bernsteinian language of description for mathematics classroom discourse. British Journal of Sociology of Education, 34(3), 313-332. doi:10.1080/01425692.201 2.714250

Sych, S. M. (2016). The divide between vocational and academic education. Journal of the Canadian Association for Curriculum Studies, 14(2), 43-52.

Upper Secondary School Act No. 92/2008.

Valero, P. (2006). Mathematics for all, economic growth, and the making of the citizen-worker. In T. S. Popkewitz, J. Diaz, \& C. Kirchgasler (Eds.), A political sociology of educational knowledge. Studies of exclusions and 
difference (pp. 117-132). London: Routledge.

Ward, S. (2012). Neoliberalism and the global restructuring of knowledge and education. New York: Routledge.

Weis, L., Cipollone, K., \& Jenkins, H. (2014). Class warfare. Class, race, and college admissions in top-tier secondary schools. Chicago: The University of Chicago Press.

Whitty, G. (2012). Social class and school knowledge: Revisiting the sociology and politics of the curriculum in the 21st century. In H. Lauder, M. Young, H. Daniels, M. Balarin, \& J. Lowe (Eds.), Educating for the knowledge economy? (pp. 212-238). London: Routledge.

Young, M., \& Muller, J. (2013). On the powers of powerful knowledge. Review of Education, 1(3), 229-250. doi:10.1002/rev3.3017

Valgerður S. Bjarnadóttir. (2018).

Building bridges and constructing walls: Subject hierarchies as reflected in teachers' perspectives towards student influence.

Netla - veftímarit um uppeldi og menntun. Sérrit 2018 - Framhaldsskólinn í brennidepli.

Menntavísindasvið Háskóla Íslands.

Sótt af http://netla.hi.is/serrit/2018/framhaldskolinn_brennidepli/04.pdf

DOI: https://doi.org/10.24270/serritnetla.2019.4 